\title{
The Evolutionary Dimensions of Global Investment Networks
}

\author{
Ronghao Jiang ${ }^{1}$ and Tenzin Tamang ${ }^{1+}$ \\ ${ }^{1}$ Erasmus University Rotterdam, the Netherlands
}

\begin{abstract}
Numerous studies focus on understanding the organization and operations of global economic and production networks. However, the evolution of the spatial and structural dimensions of these networks has rarely been explored. Drawing on the foreign direct investment (FDI) data from the Zephyr Mergers and Acquisitions (M\&A) database, this article investigates the evolutionary patterns of global economic networks from 2000 to 2007 and from 2008 to 2016 (the years preceding and following the financial crisis). First, using social network analysis, we illuminated the network properties of the global FDI flows. Second, we employed a fractional logit panel model to reflect the influences on this evolution. The results reveal major shifts in all network properties explored in the pre-crisis period while relatively gradual growth and minor shifts characterized the post-crisis period. Urban connectivity of nations was found to be significant for FDI in the post-crisis period. Significant variations in the locational attributes between the two periods are also demonstrated.
\end{abstract}

Keywords: Globalization, Networks, Evolution, Foreign Direct Investment (FDI), Global Financial Crisis

\section{Introduction}

Globalization has amplified human activities beyond national borders on economic, social, political, or technological grounds, leading to closer integration of countries around the world through connections and flows of goods, information, capital, and people (Goldin and Reinert, 2007). In this scenario, a new economic system has emerged that is increasingly built on interdependencies implemented through complex investment linkages, trade dealings, or supply chains (Schweitzer et al., 2009). This development has generated opinions about a "borderless" world where places are considered territorial units involved in external orientations and multi-scalar relations (Amin, 2002). Dicken et al. (2001) even argued that in this complex and interdependent economic system, networks have grown into a foundational unit of analysis through which the global economy is better understandable, rather than through firms and places.

Although there is considerable literature on various global networks that focuses on understanding

\footnotetext{
+Corresponding Author: Tenzin Tamang

Senior Analyst, LT Associates, Olakha, Thimphu Bhutan \#00975-16917297, Email: teny606@gmail.com

Co-Author: Ronghao Jiang

Ph.D. Candidate, University of Hongkong, Email: u3006307@connect.hku.hk
} 
the role of cities/nations as loci of action in this network system (Smith \& Timberlake, 2001; Alderson \& Beckfield, 2004; Wall \& Knaap, 2011; Sigler \& Martinus, 2017); it tends to rely largely on a specific time-space context. Little of the literature probes the change and continuity of networks over time, and an understanding of network evolution remains sketchy (Clegg et al., 2016) and is newly emerging (Cassi et al., 2012). This may be attributable to a lack of appropriate network data and tools for the exploration of the dynamic behavior and evolutionary patterns of the networks that bind places to the world system.

This paper extends the limits of existing evolutionary research. First, the paper analyzes the evolutionary patterns of global economic networks for two periods: before the financial crisis (2000-2007) and after the financial crisis (2008-2016). Second, this paper reflects on the factors that may have influenced the evolution of these economic networks and if and how they vary in the two periods. Third, in most of the extant network studies in economic geography, cities are the unit of analysis. However, our study was not conducted at the city level because city-level global data on economic network indicators are not readily available. Nonetheless, this study examines the role of cities in determining the global foreign direct investment (FDI) linkages of countries. Therefore, this study adds a fresh dimension to existing literature and contributes to theory.

The economic networks explored in this study concern the FDI linkages between nations worldwide. FDI is considered to be one of the most important economic flows in the global economy. It serves as the source of capital for developing countries and as an investment for developed countries (Milner, 2014). Primarily FDIs are composed of both greenfield investments and mergers and acquisitions (M\&As). However, this study employs only cross-border M\&A FDIs in its analysis. Brakman and Garretsen (2008) argued that in 1999 M\&As exceeded 80\% of the total value of FDIs and that they are more important in terms of FDIs than greenfield investments. In contrast, most extant studies on FDI have concentrated on greenfield FDIs. This is the fourth contribution of this study.

Finally, the study also makes an empirical and methodological contribution to the field. The study is based on a unique dataset concerning the global country networks of M\&A FDI. There are not many existing empirical studies based on similar datasets. In terms of methodology, the global FDI networks are analyzed using several methods and techniques. First, using the tools of the Geographic Information System (GIS) and network analysis, the network properties of global FDI were illuminated. Second, the influences on network evolution were reflected by employing a fractional logit panel model. These methods are relatively fresh and bridge the disciplines of geography, network science, and economics.

A networked economic system consists of many actors; therefore, the consequential systemic effects and conduct are often erratic. An understanding of the network's evolution over time and the forces that underlie that evolution is necessary (Schweitzer et al., 2009). This study 
will provide a deep understanding of how the global economic landscape has changed over time. It will also discuss the driving forces behind the evolution of the global economic landscape. This information, in turn, may encourage heightened economic resilience and competitiveness by diagnosing local economic conditions and developing adaptation and transformation strategies.

This paper is organized into five parts. Section 1 provides the introduction and the evaluation of theories on network evolution and FDI. Section 2 is the methodology. In Section 3, we discuss the empirical results, followed by a discussion in Section 4, and our conclusions are in Section 5.

The results of this study reveal three key findings. First, through describing the network properties, such as network density, spatial distribution, positionality, and structural positioning of countries, the study demonstrates that the world investment network has indeed changed from 2000 to 2016. However, distinct evolutionary patterns are seen for each period, where sharp growth and major shifts in all the properties explored are witnessed in the pre-crisis period, but there is relatively gradual growth and minor shifts after the financial crisis. Second, a country's urban attributes are significant in determining its global investment linkages. However, in the post-crisis period, first-tier cities (cities with higher global connectivity) were found to be more important than dense cities (the size of the city). Third, after the global crisis, multinationals demonstrated significant shifts in their perspectives on locational attributes. Factors that reveal more about the functioning of an economy like institutional quality and domestic credit to the private sector were found to be significant in the post-crisis period.

\section{A. Theoretical context}

\section{Network evolution and economic geography}

There have been significant theoretical developments in the field of evolutionary economic geography over the past few decades. Research in the field has moved away from traditional economic analysis and has brought in diverse heterodox concepts from fields outside economics (Martin \& Sunley, 2007). Besides the generalized Darwinism perspective and path dependence thinking that has been most frequently invoked in economics, new approaches using complex adaptive systems have been increasingly applied (Boschma \& Martin, 2010). While generalized Darwinism centers on the concepts of variety, selection, novelty, and retention (Witt, 2003), path dependence was inspired by the works of Paul David and Brian Arthur and is concerned with giving economics a historical perspective (Boschma \& Martin, 2010).

In contrast, complexity approaches are rooted in equilibrium thermodynamics theories and offer a more useful analysis of the structuration process overtime (Foster, 2005). Complexity deals with the economy as a system in constant interaction and motion and not in equilibrium, perpetually displaying internal order and self-organization. From an evolutionary perspective, 
analyzing how network agents evolve is a way of dealing with complex systems. With the growing awareness of the importance of networks in shaping the economic landscape, more studies have attempted to describe and explain various network structures using the tools of social network analysis. However, network studies in evolutionary economic geography are still in their infancy (Boschma \& Martin, 2010).

This paper contributes to the emergent field of network evolution studies, which is still underdeveloped. Hence, the first part of this study explains how the global economic landscape has changed over time (from the pre- to post-crisis periods) through the spatial distributions of FDI networks. This is important because globalization is not an end-state. Rather, it is "a complex, indeterminate set of processes operating very unevenly in both time and space" (Dicken, 2011, p. 8). Adding to an already complex process, the global financial crisis (2007-2008) has had significant implications for the global economy. There have been debates over the strength of global economic networks after the crisis. On the one hand, there is a strand of the literature that suggests the emergence of de-globalization, demonstrated through shrinking metrics of economic globalization such as FDI, trade, and bank loans (Tuca, 2013; Turok et al., 2017; Van Bergeijk, 2017). On the other hand, other researchers argue that the financial crisis has accelerated the global production system, rather than collapse it (Coe, 2012; Gereffi, 2014; Neilson et al., 2014). In the context of this theoretical backdrop, this paper contributes fresh evidence on this highly contested topic.

\section{FDI theories}

The second part of the study focuses on the factors that drive FDI and that may have profoundly affected the evolution of global FDI networks in the pre- and post-crisis periods. In the context of the driving factors of FDI, there are several theories devoted to explaining the key drivers of internationalization of firms and FDI, such as the production cycle theory (PLC), the internalization theory, capital market theory, and the eclectic paradigm. First, the production cycle theory; it is grounded in the concepts of technological innovation and market expansion and asserts that the firms undergo cycles of innovation, growth, maturity, and decline.

First, products are said to be invented, produced, and traded in local markets. Depending on the product's success, production magnitude is increased or decreased. In the case of production growth, new markets are penetrated, which improves exports. This explains the transition from the innovation phase to the growth phase to the maturity phase. In the maturity phase, firms are expected to develop production facilities in foreign sites that offer the lowest input costs both to meet growing demand and to get an edge over the company's competitors. Following this, the exporter country becomes the importer of its invented products, resulting in a phase-out and a decline. The cycle continues provided the firms are innovative in the development of new products (Nayak \& Choudhury, 2014). 
Second, the internalization theory introduces the idea that firms develop their internal markets by extending direct operations of the firm to command and control of activities handled by intermediates and by downsizing costs within the firm (Morgan \& Katsikeas, 1997). Third, the capital market theory proposes that FDI inflows are largely influenced by capital market imperfections - differences between the currency strength of the host and destination countries (Nayak \& Choudhury, 2014). According to this theory, countries with weaker currencies will be better able to attract FDI compared to economies with stronger currencies. However, this theory has a major drawback. It is unable to explain FDI flows between two countries with similar currency strengths or even the investment flows from firms in developing countries with weaker currencies to firms in developed countries with stronger currencies (Makoni, 2015).

The most well-known FDI theory is the eclectic paradigm also known as the OLI model. This theory by Dunning (2001) underscores the importance of three conditions that firms consider when engaging in FDI: the (O) ownership, (L) location advantages, and (I) internalization. The first advantage relates to tangible or intangible ownership assets of a firm over other firms in a particular market. This may be in the form of trademarks, patents, information, or technology. The second refers to availability of raw materials or certain local endowments such as labor costs, tariff barriers, or favorable policies. The third condition is the international environment that would make it advantageous for the firm to internalize rather than to outsource production (externalization) (Dunning, 2001).

The OLI model, which also includes most of the other FDI theories, allows analysis of the market advantages, based on the firm's needs and on the international environment. However, this study pursues the analysis of FDI drivers through a different lens, integrating the roles of cities and their connectivity, past investments, and place-specific factors. To investigate the factors influencing the evolution and transformation of global FDI networks, this study considers the global FDI connectivity of each country in the period to be an outcome of three factors: urban characteristics (size and connectivity) of a country, path dependence drawn from the evolutionary economic theories, and location factors drawn from the OLI paradigm. The concept of urban attributes is drawn from the extant literature on "world cities" and "global cities." These cities are conceptualized as the hubs of advanced services and information-processing activities. They are also considered the centers of leading finance and business services (Hall, 1966; Friedmann, 1986; Sassen, 1994).

The role of a country's urban attributes in determining FDI flows has been conceptualized and often asserted, but it has been overlooked in the literature for the most part, and it has not been demonstrated. Hence, this study's primary interest is to investigate the role of a country's urban attributes in determining its global FDI ties. This study examines the importance of cities in terms of both scale and global connectivity in determining countries' global FDI linkages. The few studies that examine the relationship between urban attributes and FDI are 
primarily based on the idea of urban scale, wherein the size of the city's population is an indicator of a nation's urban characteristics (Neal, 2011a). However, a city's significance is not primarily associated with its size, but rather with its accessibility, openness, and connectivity (Iammarino \& McCann, 2013).

Further, to derive a refined understanding of the factors that shape the global FDI network, the overall analysis is broken down into pre- and post-crisis analyses to uncover if and how the factors shaping it vary in the two periods. There is a plethora of work on FDI drivers based on varied geographies that demonstrate the importance of factors such as well-developed ICT infrastructure in Africa (Ibrahim et al., 2019), suppliers for intra-Arab FDI inflows (Sekkat 2014), market size, per capita income, policy reforms like free trade agreements in Southeast Asia (Ismail et al., 2009), ease of communication (Jeon et al., 2005) and proximity, similitudes in legal rules, market access, and financial openness in OECD countries (Bertrand et al., 2007). However, the shifting dynamics of FDI across periods marked by external disturbances remain unexplored.

Examination of the shifting dynamics of FDI across these periods is important because a consequence of the 2007 global recession may have been a decline in trade and investment flows due to increased national protectionism caused by higher patriotic sentiments (Bradsher \& Russel, 2017). There could be considerable impacts on the development of economies due to such decline. The impacts could be particularly harsh for fragile economies that require more external financial opportunities (Turok et al., 2017).

\section{Methodology}

This study primarily used bilateral M\&A FDI data for 219 economies worldwide in the period (2000-2016) compiled from the Zephyr M\&A database. Additional datasets were also included in the analysis.

\section{A. Evolution and structural analysis of the global economic network}

Analysis of the evolution of the global FDI network requires a discussion of basic network indices such as network density and the number of linkages over time. Network density means the proportion of possible connections in a network that are actualized by the members of the network. A possible connection is a tie that could potentially exist between two actors, whether or not it does. Network density can be represented as follows, where $n$ is the number of nodes in the network.Second, worldwide FDI network-binding countries are mapped and visualized using GIS techniques to study the spatial distribution of global FDI. Third, social 
network analysis was employed to reveal the shifting network positions of countries from 2000 to 2016. Three network measures of centrality were used: indegree, outdegree, and degree centrality (total). This involves the idea that the relational configurations between actors in the network determine their position in the network.

Degree centrality is a measure of basic network centrality. It is often used as a primary indicator when studying networks (Wasserman \& Faust, 1994). This represents the total number of ties directed to and from the actor. Indegree centrality reveals the number of incoming ties to an actor, and outdegree indicates the number of outgoing connections from an actor to others. In the literature on city networks, indegree is said to reveal the prestige of a city/nation and outdegree provides a measure of the economic influence of a city/nation on others (Alderson \& Beckfield, 2004). Other studies, like Wall (2009), argue that indegree is a measure of the dependency of a nation on other nations.

The degree centrality formula is as follows:

$$
C_{D}(i)=\sum_{j \neq i}^{N} a_{i j}
$$

In Formula 1, for a focal node (country) $i, j$ represents all other nodes. $N$ is the total number of nodes, and $a$ is the adjacency matrix, in which $a_{i j}$ is defined as 1 if node $i$ is connected to node $j$, and 0 otherwise. According to De Benedictis et al. (2014), it is better to calculate degree centrality in a normalized form because it relies on the number of existing nodes in a network, and it is difficult to compare networks of different node sizes.

A normalized degree centrality formula is as follows:

$$
C_{D}^{N}(i)=\sum_{j \neq i}^{N} a_{i j} x \frac{1}{(N-1)}
$$

The indegree and outdegree formulas are as follows:

$$
C_{I}\left(n_{i}\right)=\frac{x+i}{g-1} \text { and } C_{o}\left(n_{i}\right)=\frac{x i+}{g-1}
$$

In Formula 3, the indegree $C_{I}$ of country $n_{i}$ is the number of links received by country $i$, represented by $x+i$. Similarly, $g-1$ epresents the maximum number of ties linking $i$ to $j$. The outdegree $C_{O}$ of country $n_{i}$ is where $x i+$ represents the number of ties sent from country $i$, and $g-1$ is the maximum number of possible ties linking $i$ to $j$ (Wasserman \& Faust, 1994).

Finally, this research employs blockmodeling techniques using Pajek to calculate network 
partitions (Batagelj \& Mrvar, 2014). This method makes it possible to identify the dynamic Core-Periphery patterns of the entire network. This method enables the decomposition of the nodes and linkages into a few positions (Glückler \& Panitz, 2016). This identifies homogeneous groups of economies that share similar positions according to their centrality measures (Cassi et al., 2012). Thus, generating blocks by blockmodeling allows the different roles of countries to be categorized within the world system. By observing the change from 2000 to 2016, this assessment shows the extent of positional mobility in greater detail.

To observe this change, we employed the equivalence criteria proposed by Glückler and Panitz (2016) to pre-specify and process a relational model for judging the structure of the global FDI network. This model assumes that the countries are to be partitioned into five blocks in terms of Core-Periphery patterns - namely, Core, Integrated, Satellite, Peripheral, and Isolate. The Core block consists of countries that have both inward and outward investment connections with partners in other network positions like the Peripheral, Satellite, and Integrated positions. The exception is for Isolate countries. Countries in the Integrated block show connections with the Core and Integrated economies, but they do not have Peripheral and Satellite around them; countries in the Satellite block rely only on connections directed from and to Core economies; countries in the Peripheral block display only inward relations with Core countries. Isolate countries are completely disconnected from the global network.

\section{B. Evolution factors}

As a measure of the global FDI network, degree centrality in a normalized form is used as the dependent variable. This is drawn from De Benedictis et al. (2014), who claimed that degree centrality can be calculated better in a normalized form because it relies on the number of existing nodes in a network, and it is difficult to compare networks of different node sizes. In this, the dependent variable becomes a fractional response variable. Hence, a fractional logit model was adopted for the analysis because it is suitable for bound data (Papke \& Wooldridge, 2008). The data used is panel/longitudinal data covering the period (2000-2016), which not only improves accuracy but also captures the complexity of the dynamic behavior (Bond, 2002; Hsiao, 2007). Accordingly, this study employs a fractional logit panel regression estimated by a generalized estimating equation that can be represented as follows:

$$
Y_{i t}=\alpha+\beta_{1} X_{1 i t}+\ldots+\beta_{n} X_{n i t}+\varepsilon_{i t}
$$

In Formula 4, $Y$ is the dependent variable (degree centrality); $X_{1 i t} \ldots X_{n i t}$ are the explanatory variables, in which $i=$ entity and $t=$ time; $\beta_{1} \ldots \beta_{n}$ are the coefficients of the explanatory variables; $\alpha$ is the constant, and $\varepsilon_{i t}$ is the stochastic error term. 
To investigate the factors that influence the evolution and transformation of global economic networks, the analysis considers that the global FDI connectivity of each country in the period as an outcome of three factors: the urban characteristics of a country, path dependence, and location factors. However, this study's primary interest is to test the role of a country's urban attributes in determining its global FDI ties; therefore, path dependence and location factors are used as control variables in the analysis.

Cities provide larger infrastructure, economic, social, and cultural amenities compared to geographically dispersed locations (Dicken, 2007). Hence, large urban centers commonly hold the advantages of human capital, knowledge, and technology (McCann, 2008). Accordingly, agglomerated urban regions are likely to attract more foreign investments (Dogaru et al., 2014; Ascani et al., 2016). The urbanization rate obtained from the World Development Indicators (WDI) of the World Bank is used as the first indicator of urban characteristics of each country. Furthermore, it is important to note that an international or a global city is not primarily associated with the size of the city but rather with its degree of accessibility, openness, and connectivity (Iammarino \& McCann, 2013). Hence, cities were classified in terms of their global connectivity by the Globalization and World Cities (GaWC) Research Network. They were classified into alpha-, beta-, and gamma-level cities and cities with sufficient services. This study developed the following three categories of countries to evaluate the role of cities in determining a nation's global FDI connectivity. The first category is countries with a first-tier world city. These countries have at least one first-tier (alpha) world city. The second category is countries with a second-tier world city. These countries do not host a first-tier world city but have at least one second-tier (beta- and gamma-level) world city. The third category is countries without any world cities. These distinctions are estimated using dummy variables.

The literature maintains that economic systems or processes are outcomes of their histories (Martin \& Sunley, 2006; MacKinnon et al., 2009). They inherit the legacy of past institutional and industrial development, which impacts their future development and evolution (Yang, 2013). Therefore, the model's path dependence indicator is the FDI value of the year previous to the year of analysis. For instance, for the year 2000, path dependence is measured by the FDI value of the year 1999. Last, we contemplate location as a determinant of FDI network evolution by drawing from Brienen et al. (2010) and Burger et al. (2012) . These studies revealed the following four FDI motivations: first, expansion of markets (foreign-market-seeking FDI) wherein the market size and accessibility play a key role; second, cost reduction through channels of taxes, trade costs, and labor wages, as well as the available subsidies in a host country (efficiency-seeking FDI); third, procurement of certain resources, including local partners with the knowledge to exploit these resources (resource-seeking FDI); and fourth, strategic asset-seeking FDI in which multinationals target long-term strategic objectives to enhance their international competitiveness by obtaining assets, technological capabilities, and expertise. 
Based on these motivations, we include the following indicators to quantify the location attributes: total population of a country (market size), trade freedom (market accessibility and openness); government spending (market efficiency), GDP per worker (labor productivity or human capital), unemployment rate (labor market condition that would influence labor wage rate), high-tech export per capita (technological advancement), and share of fuels export (availability of natural resources). Further, borrowing other important location factors like national performance (Wall, 2009), institutional quality (Rodríguez-Pose, 2013), and financial development (Shah, 2016), we include GDP growth (national performance), governance index (institutional quality), and domestic credit to the private sector (financial development) in the model. The data on all the indicators were obtained from the WDI and UNCTAD with the exception of trade freedom and government spending, which were acquired from the Heritage Foundation. (Tables A and B in the Appendix show the dependent and explanatory variables, indicators, and data sources).

\section{Results}

\section{A. Basic properties and spatial evolution}

The first part of the study analyzes the evolutionary patterns of global economic networks for two periods, before the financial crisis (2000-2007) and after (2008-2016). For this, we started with the examination of changes in network density and the number of linkages in the global FDI network. The network indices were constructed and calculated for 219 countries. From Table 1, we can make out the following three trends: first, the network density and number of linkages in the network increased sharply between the years 2000 to 2007. Second, there was a falling trend in both density and numbers of linkages from 2008 to 2010. Third, there was gradual growth from 2010 to 2015, followed by a decline in 2016. The growth pattern demonstrates that integration of countries worldwide through FDI doubled from 2000 to 2007. The density increased from 0.02 in 2000 to 0.045 in 2007. Similarly, the number of global FDI linkages increased from 977 to 2,173 from 2000 to 2007 . There was a fall from 2008 to 2010 , and then there was a relatively gradual degree of network growth from 2011 to 2016 . The density and linkages increased from 0.043 to 0.044 and 2,060 to 2,133, respectively. 
Table 1. Basic Indices of the Global Network

\begin{tabular}{lccccccccc}
\hline \multicolumn{1}{c}{ Year } & 2000 & 2001 & 2002 & 2003 & 2004 & 2005 & 2006 & 2007 \\
\hline Density & 0.020464 & 0.020654 & 0.025407 & 0.031545 & 0.034058 & 0.039357 & 0.041976 & 0.045515 \\
Number of Linkages & 977 & 986 & 1213 & 1506 & 1626 & 1879 & 2004 & 2173 \\
Std Dev & 0.141582 & 0.142222 & 0.157359 & 0.174784 & 0.181378 & 0.194444 & 0.200533 & 0.208432 \\
Average Degree & 4.461187 & 4.502283 & 5.538813 & 6.876712 & 7.424657 & 8.579908 & 9.150685 & 9.922375 \\
\hline & 2008 & 2009 & 2010 & 2011 & 2012 & 2013 & 2014 & 2015 & 2016 \\
\hline Density & 0.04744 & 0.04312 & 0.041327 & 0.043149 & 0.043568 & 0.044678 & 0.048804 & 0.049202 & 0.044678 \\
Number of Linkages & 2265 & 2059 & 1973 & 2060 & 2080 & 2133 & 2330 & 2349 & 2133 \\
Std Dev & 0.212583 & 0.20314 & 0.199046 & 0.203192 & 0.204131 & 0.206595 & 0.215458 & 0.216289 & 0.206595 \\
Average Degree & 10.34247 & 9.40182 & 9.009132 & 9.406393 & 9.497717 & 9.739726 & 10.63927 & 10.72603 & 9.739726 \\
\hline
\end{tabular}

(Source) Zephyr M\&A database (Table generated by the Authors, 2020).

Then, using GIS techniques, the spatial distribution patterns of the global FDI networks were mapped and visualized. Figure 1 presents the spatial patterns of the networks for the years 2000, 2008, and 2016 based on which descriptions are made. The comparison of patterns with less time differences provide non-differentiable and inconsequential interpretations. The green and blue dots in Figure 1 show the indegree (inward FDI) and outdegree (outward FDI) of countries, respectively. The size of the dots is weighted, meaning it is proportional to each country's respective indegree and outdegree measures. The red lines represent the aggregate number of investments between countries with at least five links, and the yellow lines reveal investment ties that have fewer than five connections.

From Figure 1, the integration of countries through FDI was dramatic in the pre-crisis period (2000 to 2007). Conversely, from 2008 to 2016, the changes in the global FDI linkages were trivial. In 2000, countries in the African and South-American region were sparsely integrated within the global investment network; however, significant evolution in the integration patterns was seen with increasing linkages to countries in this region by the year 2008. However, despite growing integration, the volume of FDI to these regions remained relatively minor. The prominence of the European region for FDI is noticeable. This remains consistent throughout the analysis with dense distributions of large volumes of FDI in the region. Though not on par with the European region in terms of distribution, high volumes of FDI also tend to concentrate in a few locations in the North American region, which also remains consistent throughout the 2000 to 2016 period. Other evident changes in the composition of the network in the entire period is the growing role of the Asian region in the global FDI network. 
Figure 1. Global FDI Networks

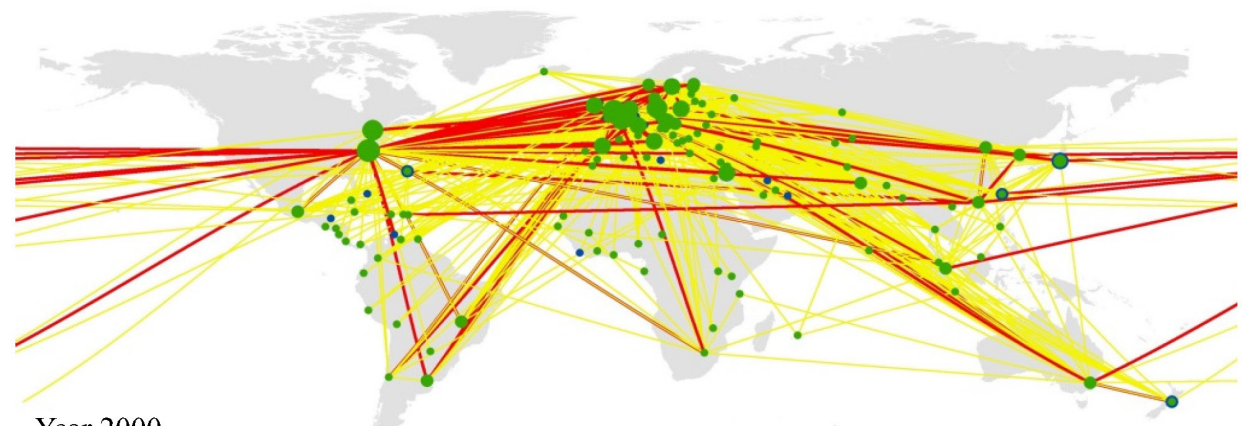

Year 2000

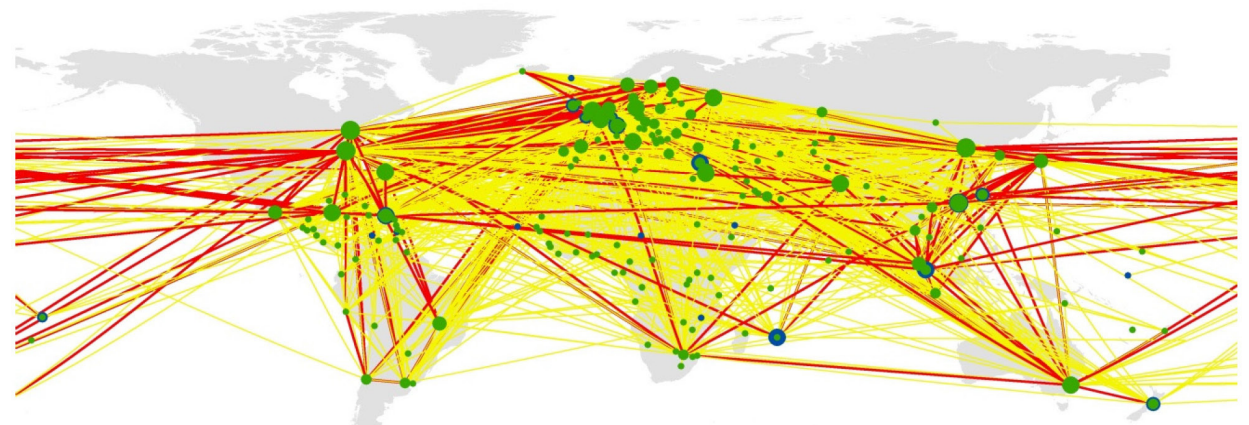

Year 2008

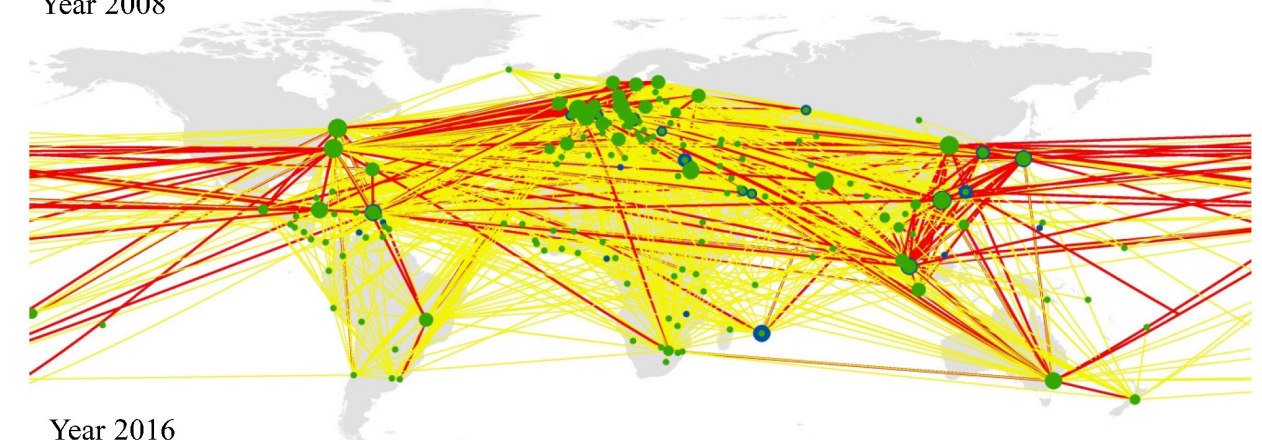

Year 2016

(Dots- countries; Lines- Investment ties); Node (country) sizes are proportional to their respective degree centrality (Source) Zephyr database (Generated using GIS by the Authors, 2020)

\section{B. Shifting positionality and the core-periphery patterns}

The GIS-generated network maps provide an overview of the spatial distribution patterns of the worldwide investment linkages in the period 2000-2016. To further understand network evolution, the shifting positionality of countries in the global FDI network during the period was analyzed using social network analysis. Table 2 presents the rankings of 15 nations based on their outdegree, indegree, and total degree scores in three different years: 2000, 2008, and 2016. The results were generated using UCINET network mapping. (Refer to Appendix Figure A for the network maps). 
Table 2. Positionality of Countries

\begin{tabular}{|c|c|c|c|c|c|c|}
\hline \multirow{2}{*}{ Rank } & \multicolumn{2}{|l|}{ Outdegree } & \multicolumn{2}{|l|}{ Indegree } & \multicolumn{2}{|l|}{ Total degree } \\
\hline & Country & Score & Country & Score & Country & Score \\
\hline \multicolumn{7}{|l|}{2000} \\
\hline 1 & United States of America & 67 & United Kingdom & 52 & United Kingdom & 115 \\
\hline 2 & United Kingdom & 63 & United States of America & 46 & United States of America & 113 \\
\hline 3 & France & 58 & Germany & 30 & Germany & 87 \\
\hline 4 & Germany & 57 & France & 27 & France & 85 \\
\hline 5 & Netherlands & 49 & Italy & 25 & Netherlands & 72 \\
\hline 6 & Switzerland & 43 & Netherlands & 23 & Switzerland & 64 \\
\hline 7 & Belgium & 36 & Austria & 21 & Italy & 59 \\
\hline 8 & Spain & 35 & Belgium & 21 & Belgium & 57 \\
\hline 9 & Sweden & 35 & Canada & 21 & Sweden & 54 \\
\hline 10 & Italy & 34 & Hungary & 21 & Spain & 51 \\
\hline 11 & Denmark & 31 & Switzerland & 21 & Austria & 49 \\
\hline 12 & Norway & 31 & Australia & 20 & Denmark & 48 \\
\hline 13 & Austria & 28 & Czech Republic & 20 & Norway & 48 \\
\hline 14 & Finland & 27 & Hong Kong & 20 & Canada & 44 \\
\hline 15 & Japan & 24 & Israel & 19 & Finland & 44 \\
\hline \multicolumn{7}{|l|}{2008} \\
\hline 1 & United States of America & 109 & United States of America & 68 & United States of America & 177 \\
\hline 2 & United Kingdom & 90 & United Kingdom & 62 & United Kingdom & 152 \\
\hline 3 & Netherlands & 74 & Canada & 53 & Netherlands & 116 \\
\hline 4 & France & 70 & China & 52 & Canada & 114 \\
\hline 5 & Germany & 63 & Germany & 48 & Germany & 111 \\
\hline 6 & Canada & 61 & India & 47 & France & 107 \\
\hline 7 & Switzerland & 59 & Russian Federation & 45 & India & 101 \\
\hline 8 & Japan & 56 & Spain & 45 & Russian Federation & 98 \\
\hline 9 & India & 54 & Italy & 43 & Spain & 95 \\
\hline 10 & Russian Federation & 53 & Netherlands & 42 & China & 94 \\
\hline 11 & Spain & 50 & Singapore & 41 & Australia & 89 \\
\hline 12 & Australia & 49 & Australia & 40 & Italy & 88 \\
\hline 13 & Sweden & 49 & France & 37 & Switzerland & 88 \\
\hline 14 & United Arab Emirates & 49 & Brazil & 34 & Japan & 83 \\
\hline 15 & Denmark & 48 & Hong Kong & 32 & Singapore & 81 \\
\hline \multicolumn{7}{|l|}{2016} \\
\hline 1 & United States of America & 100 & United States of America & 69 & United States of America & 169 \\
\hline 2 & United Kingdom & 85 & United Kingdom & 61 & United Kingdom & 146 \\
\hline 3 & France & 70 & Germany & 50 & Germany & 115 \\
\hline 4 & Netherlands & 68 & Czech Republic & 48 & Netherlands & 114 \\
\hline 5 & Germany & 65 & Canada & 47 & France & 113 \\
\hline 6 & Switzerland & 60 & China & 46 & Canada & 101 \\
\hline
\end{tabular}


Table 2. Continued

\begin{tabular}{|c|c|c|c|c|c|c|}
\hline \multirow{2}{*}{ Rank } & \multicolumn{2}{|c|}{ Outdegree } & \multicolumn{2}{|c|}{ Indegree } & \multicolumn{2}{|c|}{ Total degree } \\
\hline & Country & Score & Country & Score & Country & Score \\
\hline \multicolumn{7}{|l|}{2016} \\
\hline 7 & Canada & 54 & Netherlands & 46 & China & 100 \\
\hline 8 & China & 54 & Spain & 44 & Switzerland & 98 \\
\hline 9 & Australia & 52 & France & 43 & Australia & 92 \\
\hline 10 & Singapore & 52 & Australia & 40 & Singapore & 91 \\
\hline 11 & Japan & 48 & India & 39 & Spain & 88 \\
\hline 12 & Luxembourg & 48 & Singapore & 39 & Sweden & 80 \\
\hline 13 & Cayman Islands & 46 & Switzerland & 38 & India & 75 \\
\hline 14 & Hong Kong & 45 & Poland & 37 & Japan & 73 \\
\hline 15 & Spain & 44 & Sweden & 37 & Russian Federation & 73 \\
\hline
\end{tabular}

(Source) Zephyr M\&A database (Table generated by the authors, 2020)

In 2000 , the top 15 countries in terms of all three centrality measures are dominated by European countries, with only a few countries from other regions. In terms of outdegree, the only 2 countries outside Europe are the United States of America (USA) and Japan. Similarly, merely 5 non-European locations - the USA, Canada, Australia, Hong Kong, and Israel—fall in the top 15 destinations for inward FDI. The USA takes the top spot for outdegree but falls behind the United Kingdom (UK) for inward FDI, taking the second spot.

By 2008, there have been significant shifts in the outdegree, indegree, and total degree centralities of nations in the global FDI network with many countries outside the European region making the top 15 . While only the USA and Japan were the alien non-European countries that demonstrated strong outdegree positions in 2000, 5 new countries emerged in the top 15 list-namely Canada, India, the Russian Federation, Australia, and the United Arab Emirates. Likewise, 5 new nations - China, India, the Russian Federation, Singapore, and Brazil rose to the top 15 destinations for inward FDI. Due to these shifts in indegree and outdegree positions, in 2008, a total of 8 countries in the top 15 of the total degree measures were non-European. Further, the USA took the lead position in all three categories, whereas it had previously led in only the outdegree position.

In 2016, the network positions of countries show variations compared to 2008; however, the changes were minor. In this case, the positional shifts were observed mostly between countries that were previously in the top 15 sources and destinations for FDI. Overall, countries like the USA and the UK display strong indegree, outdegree, and degree positions in the global FDI network, continuously occupying the top 2 positions during the entire period of analysis.

Further, we employed structural positional analysis using the blockmodeling techniques in social network analysis to analyze the Core-Peripheral patterns of entire networks. The blocks 
generated will allow observation of the evolution patterns in greater detail by showing the number of countries occupying the Core, Integrated, Satellite, Peripheral, and Isolate positions in a particular period and also revealing the positional mobility that occurred from 2000 to 2016. Table 3 provides the results of blockmodeling, showing the number of countries occupying different structural positions in five different periods.

Table 3. Number of Countries in Different Structural Positions of the Global FDI Network

\begin{tabular}{|c|c|c|c|c|c|}
\hline \multirow{2}{*}{ Year } & Block 1 & Block 2 & Block 3 & Block 4 & Block 5 \\
\hline & Isolate & Peripheral & Satellite & Integrated & Core \\
\hline 2000 & 95 & 58 & 29 & 22 & 15 \\
\hline 2004 & 43 & 67 & 36 & 57 & 16 \\
\hline 2008 & 32 & 67 & 28 & 76 & 16 \\
\hline 2012 & 48 & 71 & 21 & 72 & 17 \\
\hline 2016 & 58 & 59 & 26 & 71 & 16 \\
\hline
\end{tabular}

(Source) Zephyr M\&A database (Table generated by the authors, 2020).

From Table 3, major shifts in the number of countries occupying different structural positions happened only in the Integrated and Isolate category between 2000 and 2004. There were 95 countries occupying the Isolate position in the year 2000, more than 50 percent of these countries experienced a shift in their structural position by 2004 with 43 countries remaining in the Isolate category. Only 11 of these countries experienced a shift in their structural positions between 2004 and 2008 with 32 countries remaining in the Isolate position. The number of Integrated countries increased from 22 to 57 to 76 in the 2000-2008 period. Minor shifts occurred in the other categories with the fewest being in the Core category, which only increased from 15 to 16 from 2000 to 2004 and remained the same in 2008 .

The shifts in the period (2008-2016) were somewhat unexpected. From 32 countries in the Isolate position in the year 2008, the numbers increased to 58 in 2016, suggesting that 16 more countries became completely disconnected from the global FDI network. The number of Core countries remained the same but the Integrated, Satellite, and Peripheral blocks were reduced by 5,2 , and 8 countries, respectively. The visual representation of the blocks based on geography is presented in Figure 2. It is evident that most of the Isolate and Peripheral locations are located in the African region, followed by South America, showing that a North-South divide still exists. 
Figure 2. Spatial distribution based on structural positions in the global FDI networks.
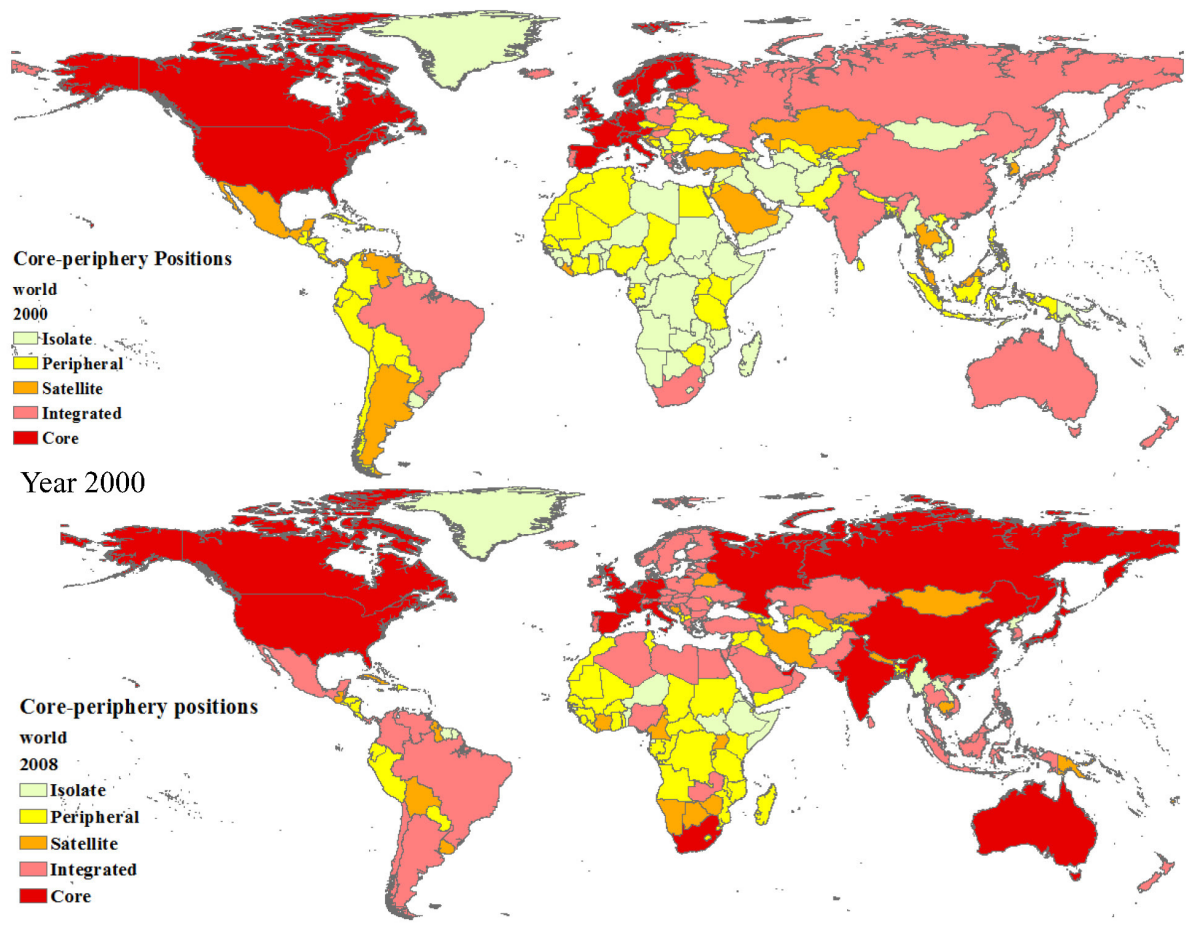

Year 2008

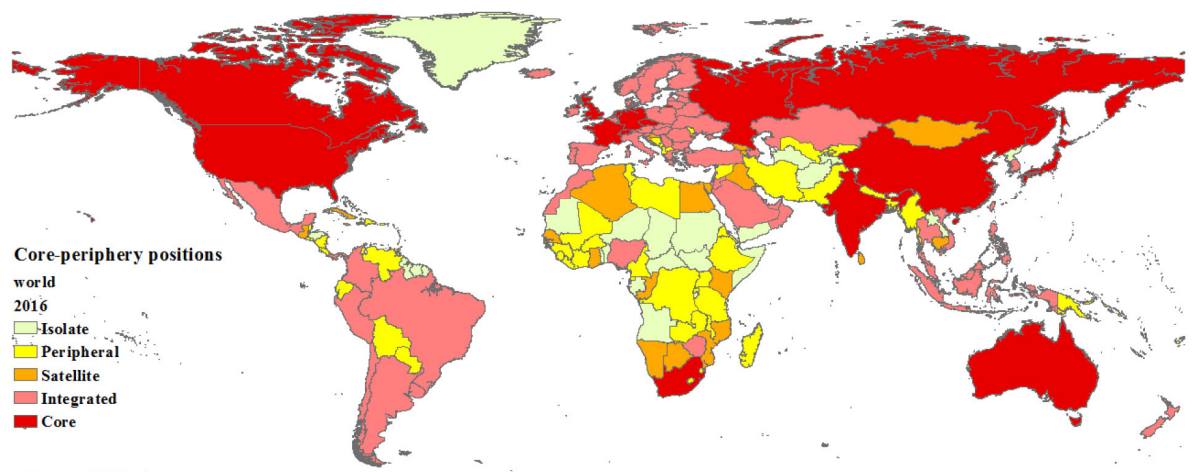

Year 2016

(Source) Zephyr database (Generated using GIS by the Authors, 2020)

\section{Empirical findings}

The second part of this study concerns the factors that influenced the evolution of global FDI networks (2000-2016). For this, a fractional logit panel regression was conducted. Caribbean financial centers like Bermuda, the Cayman Islands, and the British Virgin Islands were excluded from the models as outliers. Table 4 shows the effects of the explanatory variables, which are categorized into three broad categories-namely, urban attributes, path dependence, and 
locational attributes on the dependent variable: normalized degree centrality. The analysis was carried out using two models. Model 1 analyzed the relationship between urbanization and normalized degree centrality, controlling path dependence and locational attributes. Model 2 analyzed the relationships between countries with a first-tier world city, a second-tier world city, and no world city and normalized degree centrality, controlling other factors. In Model 2 the countries with a first-tier world city are used as a reference.

Table 4. Fractional Logit Panel Estimates of Normalized Degree Centrality (2000-2016)

\begin{tabular}{|c|c|c|}
\hline & (1) & (2) \\
\hline Urbanization & $0.797 *(0.474)$ & \\
\hline \multicolumn{3}{|l|}{ Countries with first-tier world city } \\
\hline Countries with second-tier world city & & $-0.281 *(0.166)$ \\
\hline Countries with no world city & & $-0.873 * * * \quad(0.307)$ \\
\hline (ln) Previous FDI stock & $0.089(0.060)$ & $0.041 \quad(0.069)$ \\
\hline (ln) Population & $0.503 * * * \quad(0.073)$ & $0.428 * * * \quad(0.069)$ \\
\hline Trade freedom & $0.414 * * \quad(0.171)$ & $0.419 * *(0.171)$ \\
\hline Government spending & $0.149 \quad(0.095)$ & $0.141 \quad(0.097)$ \\
\hline (ln) GDP per worker & $0.078 \quad(0.0912)$ & $0.087 \quad(0.087)$ \\
\hline Unemployment rate & $-0.630(0.572)$ & $-0.599 \quad(0.561)$ \\
\hline (ln) High-tech export per capita & $0.104 * * * \quad(0.035)$ & $0.093 * * * \quad(0.035)$ \\
\hline Share of fuels export & $0.327 *(0.192)$ & $0.413 * * \quad(0.193)$ \\
\hline GDP growth & $0.626 * * \quad(0.294)$ & $0.721 * * \quad(0.290)$ \\
\hline Institutional quality & $0.534 * * * \quad(0.0979)$ & $0.529 * * * \quad(0.0960)$ \\
\hline Domestic credit to private sector & $0.260 * * \quad(0.127)$ & $0.257 * *(0.128)$ \\
\hline Constant & $-10.17 * * * \quad(0.864)$ & $-8.229 * * *(1.172)$ \\
\hline Year dummies & Yes & Yes \\
\hline Continent dummies & Yes & Yes \\
\hline Observations & 2,568 & 2,568 \\
\hline Number of id & 171 & 171 \\
\hline Wald Chi-Square & 1333.98 & 1454.95 \\
\hline
\end{tabular}

Robust standard errors in parentheses

$* * * p<0.01, * * p<0.05, * p<0.1$

From Table 4 (Model 1), the urbanization rate is found to have a significant positive effect on normalized degree centrality. Also, Model 2 shows that countries with second-tier world cities and countries with no world cities receive significantly and substantially fewer foreign investments than countries with first-tier world cities. As claimed in the general literature, most of the variables included in the model, like the total population of a country (market size), trade freedom (market accessibility and openness), high-tech export per capita (technological advancement), share of fuels export (availability of natural resources), GDP growth (national 
performance), governance index (institutional quality), and domestic credit to the private sector (financial development) were also found to have significant positive effects on FDI flows in both Model 1 and Model 2.

Table 5 presents the results of the fractional logit regression in terms of odds ratios. From the results (Model 3 and 4), the odds of increasing the global FDI connectivity of countries with second-tier world cities (odds ratio: $0.755, p$-value: 0.1 ) and countries with no world cities (odds ratio: $0.418, p$-value: 0.01 ) are $24.5 \%$ and $58.2 \%$ lower than those with one first-tier world city, respectively. For urbanization (odds ratio: 2.219 , $p$-value: 0.1 ), with a unit increase in the urbanization rate, there is a $120 \%$ increase in the odds of countries enhancing their global FDI connectivity.

Table 5. Fractional Logit Panel Estimates (Odds-ratios) of Normalized Degree Centrality (2000-2016)

\begin{tabular}{|c|c|c|c|c|}
\hline \multirow[b]{2}{*}{ Urbanization } & \multicolumn{2}{|c|}{ (3) } & \multicolumn{2}{|c|}{ (4) } \\
\hline & $2.219^{*}$ & $(1.052)$ & & \\
\hline Countries with second-tier world city & & & $0.755^{*}$ & $(0.125)$ \\
\hline Countries with no world city & & & $0.418^{* * *}$ & $(0.155)$ \\
\hline (ln) Previous FDI stock & 1.093 & $(0.0653)$ & 1.042 & $(0.071)$ \\
\hline (In) Population & $1.654 * * *$ & $(0.121)$ & $1.534 * * *$ & $(0.106)$ \\
\hline Trade freedom & $1.512 * *$ & $(0.259)$ & $1.521 * *$ & $(0.260)$ \\
\hline Government spending & 1.160 & $(0.110)$ & 1.151 & $(0.111)$ \\
\hline (ln) GDP per worker & 1.081 & $(0.099)$ & 1.091 & $(0.095)$ \\
\hline Unemployment rate & 0.532 & $(0.305)$ & 0.549 & $(0.308)$ \\
\hline (ln) High-tech export per capita & $1.110^{* * *}$ & $(0.039)$ & $1.097^{* * *}$ & $(0.039)$ \\
\hline Share of fuels export & $1.386^{*}$ & $(0.266)$ & $1.511^{* *}$ & $(0.292)$ \\
\hline GDP growth & $1.870^{* *}$ & $(0.550)$ & $2.057 * *$ & $(0.597)$ \\
\hline Institutional quality & $1.707 * * *$ & $(0.167)$ & $1.697 * * *$ & $(0.163)$ \\
\hline Domestic credit to private sector & $1.297 * *$ & $(0.165)$ & $1.293^{* *}$ & $(0.166)$ \\
\hline Constant & $0.000^{* * *}$ & $(0.000)$ & $0.000^{* * *}$ & $(0.000)$ \\
\hline Year dummies & \multicolumn{2}{|c|}{ Yes } & \multicolumn{2}{|c|}{ Yes } \\
\hline Continent dummies & \multicolumn{2}{|c|}{ Yes } & \multicolumn{2}{|c|}{ Yes } \\
\hline Observations & \multicolumn{2}{|c|}{2,568} & \multicolumn{2}{|c|}{2,568} \\
\hline Number of id & \multicolumn{2}{|c|}{171} & \multicolumn{2}{|c|}{171} \\
\hline Wald Chi-Square & \multicolumn{2}{|c|}{1333.98} & \multicolumn{2}{|c|}{1454.95} \\
\hline
\end{tabular}

Robust standard errors in parentheses

*** $p<0.01, * * p<0.05, * p<0.1$

Last, to analyze the variations in the importance of the determinants between the pre-crisis and post-crisis periods, we repeated the previous models for the two periods: the pre-crisis period (2000-2007) and the post-crisis period (2008-2016). Table 6 reports the results of the analyses. According to Table 6 , the population urbanization rate is found to have a significant 
Table 6. Fractional Logit Panel Estimates of Normalized Total Degree Centrality (2000-2007) (2008-2016)

\begin{tabular}{|c|c|c|c|c|}
\hline & $\begin{array}{c}(5) \\
2000-2007\end{array}$ & $\begin{array}{c}(6) \\
2000-2007\end{array}$ & $\begin{array}{c}(7) \\
2008-2016\end{array}$ & $\begin{array}{c}(8) \\
2008-2016\end{array}$ \\
\hline \multirow[t]{2}{*}{ Urbanization } & $0.943 * * *$ & & 0.232 & \\
\hline & $(0.357)$ & & $(0.476)$ & \\
\hline \multicolumn{5}{|l|}{ Countries with first-tier world city } \\
\hline \multirow[t]{2}{*}{ Countries with second-tier world city } & & -0.255 & & $-0.439 * *$ \\
\hline & & $(0.156)$ & & $(0.177)$ \\
\hline \multirow[t]{2}{*}{ Countries with no world city } & & -0.385 & & $-0.955^{* * *}$ \\
\hline & & $(0.245)$ & & $(0.306)$ \\
\hline \multirow[t]{2}{*}{ (In) Previous FDI stock } & $0.188 * * *$ & $0.192 * * *$ & $0.239 * * *$ & $0.165 * * *$ \\
\hline & $(0.058)$ & $(0.064)$ & $(0.053)$ & $(0.060)$ \\
\hline \multirow[t]{2}{*}{ (ln) Population } & $0.444 * * *$ & $0.384 * * *$ & $0.295 * * *$ & $0.245 * * *$ \\
\hline & $(0.065)$ & $(0.059)$ & $(0.056)$ & $(0.055)$ \\
\hline \multirow[t]{2}{*}{ Trade freedom } & 0.121 & 0.130 & -0.150 & -0.166 \\
\hline & $(0.186)$ & $(0.196)$ & $(0.128)$ & $(0.131)$ \\
\hline \multirow[t]{2}{*}{ Government spending } & $0.559 * *$ & $0.528 *$ & 0.055 & 0.051 \\
\hline & $(0.272)$ & $(0.289)$ & $(0.066)$ & $(0.067)$ \\
\hline \multirow[t]{2}{*}{ (ln) GDP per worker } & -0.013 & 0.000 & 0.120 & 0.096 \\
\hline & $(0.054)$ & $(0.065)$ & $(0.085)$ & $(0.073)$ \\
\hline \multirow[t]{2}{*}{ Unemployment rate } & -0.614 & -0.530 & -0.232 & -0.355 \\
\hline & $(0.780)$ & $(0.739)$ & $(0.678)$ & $(0.683)$ \\
\hline \multirow[t]{2}{*}{ (ln) High-tech export per capita } & $0.138 * * *$ & $0.128 * * *$ & 0.053 & 0.044 \\
\hline & $(0.041)$ & $(0.0385)$ & $(0.042)$ & $(0.042)$ \\
\hline \multirow[t]{2}{*}{ Share of fuels export } & 0.317 & $0.418^{* *}$ & -0.181 & 0.289 \\
\hline & $(0.194)$ & $(0.210)$ & $(0.189)$ & $(0.182)$ \\
\hline \multirow[t]{2}{*}{ GDP growth } & $0.827 * *$ & $0.845^{* *}$ & 0.097 & 0.109 \\
\hline & $(0.393)$ & $(0.404)$ & $(0.337)$ & $(0.336)$ \\
\hline \multirow[t]{2}{*}{ Institutional quality } & $0.501 * * *$ & $0.519 * * *$ & $0.374 * * *$ & $0.368 * * *$ \\
\hline & $(0.113)$ & $(0.114)$ & $(0.119)$ & $(0.113)$ \\
\hline \multirow[t]{2}{*}{ Domestic credit to private sector } & 0.0612 & 0.0653 & $0.225 * *$ & $0.251 * *$ \\
\hline & $(0.106)$ & $(0.118)$ & $(0.114)$ & $(0.115)$ \\
\hline \multirow[t]{2}{*}{ Constant } & $-9.631 * * *$ & $-8.483^{* * *}$ & $-8.382 * * *$ & $-6.398 * * *$ \\
\hline & $(0.659)$ & $(0.944)$ & $(0.736)$ & $(0.975)$ \\
\hline year dummies & Yes & Yes & Yes & Yes \\
\hline Continent dummies & Yes & Yes & Yes & Yes \\
\hline Observations & 1,290 & 1,290 & 1,278 & 1,278 \\
\hline Number of id & 168 & 168 & 169 & 169 \\
\hline Wald Chi-Square & 1240.38 & 1344.01 & 959.61 & 1121.73 \\
\hline
\end{tabular}

Robust standard errors in parentheses

*** $p<0.01, * * p<0.05, * p<0.1$ 
positive effect on normalized degree centrality only in the pre-crisis period (Model 5). Model 8 demonstrates that countries with second-tier world cities and countries with no world cities received significantly and substantially fewer foreign investments than countries with first-tier world cities in the post-crisis period. Several other variables also show significant variation in the results of the two periods. While previous FDI stocks (path dependence), the total population of a country (market size), and institutional quality share positive and significant correlations with the dependent variable in both periods, government spending (market efficiency), high-tech export per capita (technological advancement), the share of fuels export (availability of natural resources), and GDP growth (national performance) share a positive and significant correlation with the dependent variable only in the pre-crisis period. On the contrary, domestic credit to the private sector, included in the model as a measure of economic development, is significant and positive only in the post-crisis period.

From Table 7, with a unit increase in the urbanization rate (odds ratio: $2.567, p$-value: 0.01 ) in the pre-crisis period, there was a $150 \%$ increase in the odds of countries enhancing their global FDI connectivity. In the post-crisis period, the odds of increasing global FDI connectivity of countries with second-tier world cities (odds ratio: $0.645, p$-value: 0.05 ) and countries with no world cities (odds ratio: $0.385, p$-value: 0.01 ) were $35.5 \%$ and $61.5 \%$ lower than those with one first-tier world city, respectively. 
Table 7. Fractional Logit Panel Estimates (Odds-ratios) of Normalized Total Degree Centrality (2000-2007) (2008-2016)

\begin{tabular}{|c|c|c|c|c|}
\hline & (9) & $(10)$ & (11) & (12) \\
\hline & $2000-2007$ & $2000-2007$ & $2008-2016$ & $2008-2016$ \\
\hline \multirow[t]{2}{*}{ Urbanization } & $2.567 * * *$ & & 1.262 & \\
\hline & $(0.918)$ & & $(0.600)$ & \\
\hline \multirow[t]{2}{*}{ Countries with second-tier world city } & & 0.775 & & $0.645^{* *}$ \\
\hline & & $(0.121)$ & & $(0.114)$ \\
\hline \multirow[t]{2}{*}{ Countries with no world city } & & 0.681 & & $0.385^{* * *}$ \\
\hline & & $(0.167)$ & & $(0.118)$ \\
\hline \multirow[t]{2}{*}{ (ln) Previous FDI stock } & $1.207 * * *$ & $1.212 * * *$ & $1.270^{* * *}$ & $1.179 * * *$ \\
\hline & $(0.070)$ & $(0.077)$ & $(0.067)$ & $(0.070)$ \\
\hline \multirow[t]{2}{*}{ (ln) Population } & $1.559 * * *$ & $1.467 * * *$ & $1.343^{* * *}$ & 1. $278^{* * *}$ \\
\hline & $(0.102)$ & $(0.086)$ & $(0.075)$ & $(0.070)$ \\
\hline \multirow[t]{2}{*}{ Trade freedom } & 1.128 & 1.139 & 0.860 & 0.847 \\
\hline & $(0.210)$ & $(0.223)$ & $(0.110)$ & $(0.112)$ \\
\hline \multirow[t]{2}{*}{ Government spending } & $1.748^{* *}$ & $1.696^{*}$ & 1.056 & 1.053 \\
\hline & $(0.473)$ & $(0.476)$ & $(0.070)$ & $(0.070)$ \\
\hline \multirow[t]{2}{*}{ (ln) GDP per worker } & 0.987 & 1.003 & 1.128 & 1.101 \\
\hline & $(0.053)$ & $(0.065)$ & $(0.096)$ & $(0.080)$ \\
\hline \multirow[t]{2}{*}{ Unemployment rate } & 0.541 & 0.589 & 0.793 & 0.701 \\
\hline & $(0.422)$ & $(0.435)$ & $(0.538)$ & $(0.479)$ \\
\hline \multirow[t]{2}{*}{ (ln) High-tech export per capita } & $1.148^{* * *}$ & $1.136^{* * *}$ & 1.054 & 1.044 \\
\hline & $(0.047)$ & $(0.044)$ & $(0.044)$ & $(0.044)$ \\
\hline \multirow[t]{2}{*}{ Share of fuels export } & 1.372 & $1.518^{* *}$ & 1.198 & 1.335 \\
\hline & $(0.267)$ & $(0.319)$ & $(0.227)$ & $(0.244)$ \\
\hline \multirow[t]{2}{*}{ GDP growth } & $2.285^{* *}$ & $2.328 * *$ & 1.102 & 1.116 \\
\hline & $(0.898)$ & $(0.940)$ & $(0.372)$ & $(0.375)$ \\
\hline \multirow[t]{2}{*}{ Institutional quality } & $1.651 * * *$ & $1.680 * * *$ & $1.453 * * *$ & $1.444 * * *$ \\
\hline & $(0.187)$ & $(0.192)$ & $(0.162)$ & $(0.164)$ \\
\hline \multirow[t]{2}{*}{ Domestic credit to private sector } & 1.063 & 1.067 & $1.252 * *$ & $1.286^{* *}$ \\
\hline & $(0.112)$ & $(0.126)$ & $(0.139)$ & $(0.148)$ \\
\hline \multirow[t]{2}{*}{ Constant } & $0.000 * * *$ & $0.000 * * *$ & $0.000 * * *$ & $0.000 * * *$ \\
\hline & $(0.000)$ & $(0.000)$ & $(0.000)$ & $(0.000)$ \\
\hline year dummies & Yes & Yes & Yes & Yes \\
\hline Continent dummies & Yes & Yes & Yes & Yes \\
\hline Observations & 1,290 & 1,290 & 1,278 & 1,278 \\
\hline Number of id & 168 & 168 & 169 & 169 \\
\hline Wald Chi-Square & 1240.38 & 1344.01 & 959.61 & 1121.73 \\
\hline
\end{tabular}

Robust standard errors in parentheses

*** $p<0.01, * * p<0.05, * p<0.1$ 


\section{Discussions}

Analysis of the evolutionary patterns of global FDI networks in the periods before and after the financial crisis reveal diverging trends in network growth. While the growth was sharp before the economic crisis, the economic integration of countries through FDI has been gradual after the crisis. This relates to studies by $\mathrm{Xu}$ et al. (2019), which claim the manifestation of new trends of regional financial cooperation that have resulted in the diminishing strength of global financial integration. Tuca (2014) also supported the idea that the economic crisis has led to a decline in globalization as many countries take isolationist measures to keep spending within national territories. The study even argues that the decline in trade and FDI worldwide are the most direct results of the economic crisis. This defines an altered international development landscape after the global financial crisis in which many economies disengaged from others to repel global market fluctuations and volatile external influences.

Furthermore, the spatial patterns of global FDI flows reveal the disproportionate geographic distribution of corporate networks (Wall \& Knaap, 2011; Carroll, 2007), dominated mostly by a "happy few" economies (Wall et al., 2011). Additionally, a new geographic distribution pattern has occurred over the period, in which growing international investment ties have led to the proliferation of new economic cores, starting with the European, then the North American, and then the Asian core. In his world city hypothesis, Friedmann (1986) described European, North American, and Asian cities as trio of powerful economies in the global hierarchy. Later, Wall (2009) argued that expanding markets led to the proliferation of these new economic cores. Also, although the African region has integrated into the global investment system over time-mostly through inward FDI, African global networks remain sparse compared to others. This was highlighted in Wall et al. (2018), which claims that the value of inward FDI to Africa accounts only for roughly $5 \%$ of world FDI, a poor percentage in comparison to the continent's population and size.

The network positions of the countries also show significant variations in the pre-crisis period with minor shifts after the crisis when the positional shifts in the top 15 were observed mostly between countries that previously were the top sources and destinations for FDI. Moreover, developed economies like the USA and the UK consistently occupied the top two places in all three centrality measures, namely indegree, outdegree, and total degree throughout the analysis. Similarly, Xu et al. (2019) also observed that the top economies in the international investment network are relatively constant, and the dominant economies were always the USA and the UK.

The results of the structural positional analysis show that major alterations in the number of countries occupying different structural positions transpired in two categories: Integrated and Isolate. Most of these changes materialized in the pre-crisis period with slight changes in the 
post-crisis period. Also, in the overall period, the number of Core countries remained more or less the same with only one country moving up in the hierarchy, increasing the number of Core countries by only one unit in the entire period (2000-2016). This corresponds to Glückler and Panitz (2016), who argued that upgrading to a Core position was not a smooth process. It requires a much higher threshold, and the majority of upgrades are concentrated in Integrated and Satellite positions. Similarly, Mahutga and Smith's (2011) analysis found stagnation in the upgrading process of Peripheral countries. Kharas and Kohli (2011) reasoned that this was happening mainly because upgrading demands mutual relationships with Core partners. This is normally difficult for less-integrated countries because they are unable to match the standards and institutions of actors in other Core markets and fail to make arrangements for distribution and supply. Glückler and Panitz (2015) also took a similar stance, arguing that to attract partners from the Core, Peripheral actors must also face the challenge of creating market intelligence about Core areas over far distances.

The analysis of the factors shaping global FDI connectivity shows that most of the locational factors included in the analysis are significant and positive for FDI flows. The empirical analysis of how urban characteristics of a country affect the global FDI network is the core of this study, and it is also demonstrated through these results. The first indicator of urban attributes of a country included in the model, namely urbanization rate, is seen to have a significant and positive effect on total FDI flows. Also, the importance of a country having first-tier world cities compared to second-tier cities and no world cities is established in the results.

This supports the concept of cities as command and control centers for multinational operations in the extant literature on world or global cities in which they have been conceptualized as the hubs for advanced services and information-processing activities. They are also considered to be the centers for leading financial and business services (Hall, 1966; Friedmann, 1986; Sassen, 1994). Likewise, Scott (2001) reasoned that the global city regions contain capital, labor, and social amenities that strengthen extra-national relationships. Further, powerful cities are said to maintain strong corporate ties with corporations in the world system, functioning as hubs of global capital (Alderson \& Beckfield, 2004) and intensifying the integration of nations through these ties.

The resulting variations in the importance of determinants between the pre-crisis and post-crisis periods show that the factors differed greatly for the two periods. The role of first-tier cities in influencing FDI flows was found to be significant only in the post-crisis period. On the contrary, the second urban attribute, the urbanization rate, was found to have a significant positive effect on global FDI flows only in the pre-crisis period. The results indicate that the size of cities was a weaker influence on FDI flows in the post-crisis period. Instead, urban connectivity are more likely to attract FDI. This corresponds to Neal's (2011b) argument that today's size-based urban hierarchies are in decline and network-based urban hierarchies due 
to the emergence of new kinds of goods and services and fresh ways of moving them are on the rise. In this situation, multinationals could thrive in smaller cities with concentrated and specialized linkages regardless of their size. This, however, does not mean that size is irrelevant, only that it is becoming less significant. Also, cities with diverse linkages endow businesses with higher value-added activities and resilience to counteract volatile economic situations (Capello et al., 2015).

Locational factors such as market size and institutional quality were significant in both periods. Market size directly translates to the unambiguous conclusion of previous empirical studies on the importance of demand size in the location choice for multinational investment. Institutional quality relates to risk assessment, which is also a key determinant of FDI (Lautier $\&$ Moreau, 2012). The quality of institutions matters because the institutional quality of a country in terms of its legal and political frameworks are vital for multinationals. After all, FDI involves many transactional costs and upright institutions can avoid expenses incurred through corruption (Prüfer \& Tondl, 2008). Whitley (1998) also argued that a place's financial and labor markets are organized through their institutional settings, determining the nature of markets and the behavior of firms. Furthermore, institutional settings are vital in generating value and capturing markets. Also, they impact the local conditions and standards of wages, labor, and work environments, which are crucial for the functioning and outcome of global production networks (Henderson et al., 2002).

Other locational factors included in the analysis show significant variation in the results for the two periods. On the one hand, financial development proxied by domestic credit to the private sector is significant only in the post-crisis period. On the other hand, locational factors like GDP growth, government spending, high-tech export, and shares of fuel export are significant only in the pre-crisis period. This indicates that, in making their location decisions, the multinationals valued different locational attributes (Dogaru et al., 2014) in the two periods; there were significant shifts in multinationals' perspectives on locational attributes after the global crisis.

We propose two possible explanations for the post-crisis significance of domestic credit to the private sector. First, we suggest that, after the crisis, multinationals followed a more resilient strategy and chose to make investments in safer markets that operate freely, competitively, efficiently, and are in a better position to cope with uncertain economic conditions. Domestic credit to the private sector allows assessment of economic freedom (Gwartney \& Lawson, 2009), portraying regulatory restraints and bureaucratic procedures on competition, and the operation of markets. Low private-sector involvement would mean that a freely-operating market is inhibited by a poor allocation of resources and low shock-absorbing resilience (Briguglio et al., 2009).

Second, with the financial constraints and low-demand shocks brought on by the crisis 
(Paunov, 2012), we suggest that domestic investment in the private sector may have climbed in significance because of its signaling effects to foreign firms about possible opportunities. This is drawn from signal theory by Macmillan (1999), which suggests domestic investments lead FDI through information about the local business climate and act as a signal to foreign firms about the condition of an economy. Likewise, Ndikumana and Verick (2008) claim that domestic investments indicate high returns to foreign firms and, therefore, stimulate FDI.

Following the same concept of resilience and signaling, the diminishing significance of locational factors like GDP growth and government spending from the pre-crisis to post-crisis period may also be anticipated. Growth in GDP indicates the rate at which economic opportunities are expanding in a country. This may guide firms about potential markets for their services and products, as well as customers' average incomes (Manyika et al., 2015). Likewise, clear signs of public spending point to both the opportunities and facilities available in a country (Buettner, 2002). Yet, in comparison, indicators such as institutional quality and domestic credit to private sectors give more accurate information on the opportunities, elements of risk, and profit expectations, and they provide a clearer picture of an economy. For instance, Lautier and Moreau (2012) claim that very poor countries also generate business and profit opportunities, but they are not noticed because they are isolated in heterogeneous niche-markets. In this context, it appears that factors such as GDP and government spending may have become less significant to investors in the post-crisis period.

Contrary to expectations, the indicator of technological advancement was not significant in the post-crisis period. First, this may be related to technology spurts across the world in the last decade. Increased accessibility of technology has leveled the field for those who typically found it hard to access foreign investments through technological innovations. For instance, Srholec (2007) claimed that developing countries were increasingly becoming exporters of hi-tech products. Some of these countries even specialized extensively in high-tech exports. Second, the heterogeneity of the sample adopted in different studies. Previous studies employed the number of internet hosts (Choi, 2003), mobile phone users (Lydon \& Williams, 2005), and telephone lines (Demirhan \& Masca, 2008) as the indicators of technological advancement, whereas our study includes high-tech exports. According to Srholec (2007), specialization in high-tech exports typically does not reflect technological capabilities, and technological content may differ across countries. Last, the indicator of a nation's natural resources (fuel export) included in the model also became insignificant in the post-crisis period. We considered this occurrence to be the result of the shifts in global value chains that are growing more knowledgeintensive and are shifting toward service sectors. Intangibles are playing a larger role than physical resources in shaping business patterns (Lund et al., 2019). 


\section{Conclusion}

Given that the extant network studies in economic geography focus mainly on a specific time-space context, this study first examined the evolutionary patterns of global FDI networks before the financial crisis (2000-2007) and after the financial crisis (2008-2016). Second, the study examined the factors that may have influenced the evolution.

The results reveal three key findings. First, the study shows that the world investment network has indeed changed in the period from 2000 to 2016 by describing properties, such as network density, spatial distribution, positionality, and structural positioning of countries. However, distinct evolution patterns were seen for each period. Sharp growth and major shifts in all the properties explored were witnessed in the pre-crisis period, but relatively gradual growth and minor shifts were observed after the financial crisis. Second, a country's urban attributes are significant in determining its global investment linkages. However, in the post-crisis period, having first-tier cities (global cities with higher connectivity) was found to be more important than the size (density) of cities. Third, significant shifts in the perspectives of multinationals on locational attributes after the global crisis have been demonstrated. Factors that reveal more about the functioning of an economy like institutional quality and domestic credit to the private sector were found to be significant in the post-crisis period. On the whole, this study outlines the changing global context of the economic integration of countries, especially after the crisis, which calls for greater awareness of both the shifting international environment for FDI and FDI motivation.

One limitation of this study is that the empirical model considers the variables to be exogenous. This potential simultaneity bias should be addressed in future research because network structures involve conditional dependencies between dyads that have communal actors (Patuelli et al., 2016; Broekel et al., 2014). Accordingly, the evolution of network actors might also be affected by the changing overall network structure. These network dependencies and network autocorrelation are not easily controlled in the existing econometric models. Hence, future research should employ recent stochastic actor-oriented models such as simulation investigation for empirical network analysis for more sophisticated analyses of the evolution and dynamics of global networks.

\section{References}

Alderson, A. S., \& Beckfield, J. (2004). Power and position in the world city system. American Journal of Sociology, 109(4), 811-851.

Amin, A. (2002). Spatialities of globalisation. Environment and Planning A: Economy and Space, 34(3), 
385-399.

Ascani, A., Crescenzi, R., \& Iammarino, S. (2016). What drives european multinationals to the european union neighbouring countries? A mixed-methods analysis of italian investment strategies. Environment and Planning C: Government and Policy, 34(4), 656-675.

Batagelj, V., \& Mrvar, A. (2014). Pajek. Encyclopedia of Social Network Analysis and Mining (pp. 1245-1256). New York: Springer.

Bertrand, O., Mucchielli, J., \& Zitouna, H. (2007). Location choices of multinational firms: The case of mergers and acquisitions. Journal of Economic Integration, 22(1), 181-209.

Bond, S. R. (2002). Dynamic panel data models: A guide to micro data methods and practice. Portuguese Economic Journal, 1(2), 141-162.

Boschma, R., \& Martin, R. (2010). The Aims and Scope of Evolutionary Economic Geography (Papers in Evolutionary Economic Geography (PEEG) 1001, Utrecht University).

Bradsher, K., \& Russel, K. (2017). Building trade walls. Retrieved from https://www.nytimes.com/interactiv e/2017/business/trade-china-protectionism.html

Brakman, S., \& Garretsen, H. (2008). Foreign direct investment and the multinational enterprise: An introduction. Foreign Direct Investment and the Multinational Enterprise (pp. 1-10). Cambridge: MIT Press.

Brienen, M. J., Burger, M. J., \& Van Oort, F. G. (2010). The geography of chinese and indian greenfield investments in Europe. Eurasian Geography and Economics, 51(2), 254-273.

Briguglio, L., Cordina, G., Farrugia, N., \& Vella, S. (2009). Economic vulnerability and resilience: Concepts and measurements. Oxford Development Studies, 37(3), 229-247.

Broekel, T., Balland, P., Burger, M., \& Van Oort, F. (2014). Modeling knowledge networks in economic geography: A discussion of four methods. The Annals of Regional Science, 53(2), 423-452.

Buettner, T. (2002). The impact of taxes and public spending on the location of FDI: Evidence from FDI-flows within Europe (Discussion Paper No. 02-17, Centre for European Economic Research).

Burger, M. J., Van der Knaap, B., \& Wall, R. S. (2012). Revealed competition for greenfield investments between european regions. Journal of Economic Geography, 13(4), 619-648.

Capello, R., Caragliu, A., \& Fratesi, U. (2015). Spatial heterogeneity in the costs of the economic crisis in europe: Are cities sources of regional resilience? Journal of Economic Geography, 15(5), 951-972.

Carroll, W. K. (2007). Global cities in the global corporate network. Environment and Planning A, 39(10), 2297-2323.

Cassi, L., Morrison, A., \& Ter Wal, A. L. (2012). The evolution of trade and scientific collaboration networks in the global wine sector: A longitudinal study using network analysis. Economic Geography, 88(3), 311-334.

Choi, C. (2003). Does the internet stimulate inward foreign direct investment? Journal of Policy Modeling, 25(4), 319-326.

Clegg, S., Josserand, E., Mehra, A., \& Pitsis, T. S. (2016). The transformative power of network dynamics: A research agenda. Organization Studies, 37(3), 277-291.

Coe, N. M. (2012). Geographies of production II: A global production network A-Z. Progress in Human Geography, 36(3), 389-402.

De Benedictis, L., Nenci, S., Santoni, G., Tajoli, L., \& Vicarelli, C. (2014). Network analysis of world 
trade using the BACI-CEPII dataset. Global Economy Journal, 14(3/4), 287-343.

Demirhan, E., \& Masca, M. (2008). Determinants of foreign direct investment flows to developing countries: A cross-sectional analysis. Prague Economic Papers, 4(4), 356-369.

Dicken, P. (2007). Global shift: Mapping the changing contours of the world economy. London: SAGE Publications Ltd.

Dicken, P. (2011). Global shift: Mapping the changing contours of the world economy (6 ed.). United States of America: The Guilford Press.

Dicken, P., Kelly, P. F., Olds, K., \& Wai-Chung Yeung, H. (2001). Chains and networks, territories and scales: Towards a relational framework for analysing the global economy. Global Networks, 1(2), 89-112.

Dogaru, T., Burger, M., Van Oort, F., \& Karreman, B. (2014). The geography of multinational corporations in CEE countries: Perspectives for second-tier city regions and european cohesion policy. Investigaciones Regionales, 29, 193-214.

Dunning, J. H. (2001). The eclectic (OLI) paradigm of international production: Past, present and future. International Journal of the Economics of Business, 8(2), 173-190.

Foster, J. (2005). From simplistic to complex systems in economics. Cambridge Journal of Economics, 29(6), 873-892.

Friedmann, J. (1986). The world city hypothesis. Development and Change, 17(1), 69-83.

Gereffi, G. (2014). Global value chains in a post Washington consensus world. Review of International Political Economy, 21(1), 9-37.

Glückler, J., \& Panitz, R. (2015). Beobachtung, begegnung und beziehung. Zeitschrift Für Wirtschaftsgeographie, 59(1), 20-33.

Glückler, J., \& Panitz, R. (2016). Relational upgrading in global value networks. Journal of Economic Geography, 16(6), 1161-1185.

Goldin, I., \& Reinert, K. (2007). Globalization for development: Trade, finance, aid, migration, and policy. Washington, DC: World Bank Publications.

Gwartney, J., \& Lawson, R. (2009). Economic freedom of the world (p.230). Vancouver: Economic Freedom Network.

Hall, P. G. (1966). The world cities. London: Weidenfeld and Nicolson.

Henderson, J., Dicken, P., Hess, M., Coe, N., \& Yeung, H. W. (2002). Global production networks and the analysis of economic development. Review of International Political Economy, 9(3), 436-464.

Hsiao, C. (2007). Panel data analysis - advantages and challenges. Test, 16(1), 1-22.

Iammarino, S., \& McCann, P. (2013). Multinationals and economic geography: Location, technology and innovation. Cheltenham: Edward Elgar Publishing.

Ibrahim, M., Adam, I. O., \& Sare, Y. A. (2019). Networking for foreign direct investment in Africa. Journal of Economic Integration, 34(2), 346-369.

Ismail, N. W., Smith, P., \& Kugler, M. (2009). The effect of ASEAN economic integration on foreign direct investment. Journal of Economic Integration, 24(3), 385-407.

Jeon, B. N., Tang, L., \& Zhu, L. (2005). Information technology and bilateral FDI: Theory and evidence. Journal of Economic Integration, 20(4), 613-630. 
Kharas, H., \& Kohli, H. (2011). What is the middle income trap, why do countries fall into it, and how can it be avoided? Global Journal of Emerging Market Economies, 3(3), 281-289.

Lautier, M., \& Moreau, F. (2012). An empirical criticism of the "FDI development" convention. Revista De Economia Contemporânea, 16(3), 393-414.

Lund, S., Manyika, J., Woetzel, J., Bughin, J., Krishnan, M., Seong, J., \& Muir, M. (2019). Globalization in transition: The future of trade and value chains. Washington, DC: McKinsey Global Institute.

Lydon, R., \& Williams, M. (2005). Communications networks and foreign direct investment in developing countries. Communications \& Strategies, 58, 43-60.

MacKinnon, D., Cumbers, A., Pike, A., Birch, K., \& McMaster, R. (2009). Evolution in economic geography: Institutions, political economy, and adaptation. Economic Geography, 85(2), 129-150.

Macmillan, M. (1999). Foreign direct investment: Leader or follower? (Discussion Paper, 99(01), Tufts University).

Mahutga, M. C., \& Smith, D. A. (2011). Globalization, the structure of the world economy and economic development. Social Science Research, 40(1), 257-272.

Makoni, P. L. (2015). An extensive exploration of theories of foreign direct investment. Risk Governance \& Control: Financial Markets and Institutions, 5(2), 77-83.

Manyika, J., Woetzel, J., \& Dobbs, R. (2015). Global Growth: Can Productivity Save the Day in an Aging World? Washington, DC: McKinsey Global Institute.

Martin, R., \& Sunley, P. (2006). Path dependence and regional economic evolution. Journal of Economic Geography, 6(4), 395-437.

Martin, R., \& Sunley, P. (2007). Complexity thinking and evolutionary economic geography. Journal of Economic Geography, 7(5), 573-601.

McCann, P. (2008). Globalization and economic geography: The world is curved, not flat. Cambridge Journal of Regions, Economy and Society, 1(3), 351-370.

Milner, H. V. (2014). Introduction: The global economy, FDI, and the regime for investment. World Politics, 66(1), 1-11.

Morgan, R. E., \& Katsikeas, C. S. (1997). Theories of international trade, foreign direct investment and firm internationalization: A critique. Management Decision, 35(1), 68-78.

Nayak, D., \& Choudhury, R. N. (2014). A Selective Review of Foreign Direct Investment Theories (Working Paper Series, No. 143). Asia-Pacific Research and Training Network on Trade (ARTNeT), Bangkok.

Ndikumana, L., \& Verick, S. (2008). The linkages between FDI and domestic investment: Unravelling the developmental impact of foreign investment in Sub-Saharan africa. Development Policy Review, 26(6), 713-726.

Neal, Z. (2011a). Differentiating centrality and power in the world city network. Urban Studies, 48(13), 2733-2748.

Neal, Z. P. (2011b). From central places to network bases: A transition in the US urban hierarchy, 1900-2000. City \& Community, 10(1), 49-75.

Neilson, J., Pritchard, B., \& Yeung, H. W. (2014). Global value chains and global production networks in the changing international political economy: An introduction. Review of International Political Economy, 21(1), 1-8. 
Papke, L. E., \& Wooldridge, J. M. (2008). Panel data methods for fractional response variables with an application to test pass rates. Journal of Econometrics, 145(1/2), 121-133.

Patuelli, R., Linders, G. M., Metulini, R., \& Griffith, D. A. (2016). The space of gravity: Spatially filtered estimation of a gravity model for bilateral trade. Spatial econometric interaction modelling (pp. 145-169). Cham: Springer.

Paunov, C. (2012). The global crisis and firms' investments in innovation. Research Policy, 41(1), 24-35.

Prüfer, P., \& Tondl, G. (2008). The FDI-growth nexus in Latin America: The role of source countries and local conditions (Working Paper, No. 2008-61). Tilburg University.

Rodríguez-Pose, A. (2013). Do institutions matter for regional development? Regional Studies, 47(7), 1034-1047.

Sassen, S. (1994). The Global city. New York, London, Tokyo: Princeton University Press.

Schweitzer, F., Fagiolo, G., Sornette, D., Vega-Redondo, F., Vespignani, A., \& White, D. R. (2009). Economic networks: The new challenges. Science (New York, N.Y.), 325(5939), 422-425. doi:10.1126/science.117 3644

Scott, A. J. (2001). Globalization and the rise of city-regions. European Planning Studies, 9(7), 813-826.

Sekkat, K. (2014). Is there anything special with intra-Arab foreign direct investment? Journal of Economic Integration, 29(1), 139-164.

Shah, M. H. (2016). Financial development and foreign direct investment: The case of Middle East and North African (MENA) developing nations (MPRA Paper 82013, University Library of Munich, Germany).

Sigler, T. J., \& Martinus, K. (2017). Extending beyond 'world cities' in world city network (WCN) research: Urban positionality and economic linkages through the Australia-based corporate network. Environment and Planning A: Economy and Space, 49(12), 2916-2937.

Smith, D. A., \& Timberlake, M. F. (2001). World city networks and hierarchies, 1977-1997: An empirical analysis of global air travel links. American Behavioral Scientist, 44(10), 1656-1678.

Srholec, M. (2007). High-tech exports from developing countries: A symptom of technology spurts or statistical illusion? Review of World Economics, 143(2), 227-255.

Tuca, S. (2013). The evolution of economic globalization during the current global crisis. CES Working Papers, 5(4), 645-653.

Tuca, S. (2014). The relationship between globalization and the economic crisis. The USV Annals of Economics and Public Administration, 14(1), 120-126.

Turok, I., Bailey, D., Clark, J., Du, J., Fratesi, U., Fritsch, M., ... \& W. Fiona. (2017). Global Reversal, Regional Revival? Regional Studies, 51(1), 1-8.

Van Bergeijk, P. (2017). One is not enough! an economic history perspective on world trade collapses and deglobalization. ISS Working Paper Series/General Series, 628, 1-23.

Wall, R., Maseland, J., Rochell, K., \& Spaliviero, M. (2018). The state of African cities 2018: The geography of African investment. Nairobi: UN-HABITAT.

Wall, R. (2009). Netscape: Cities and global corporate networks. Netherlands: Erasmus University Rotterdam. Wall, R. S., Burger, M. J., \& Van der Knaap, G. (2011). The geography of global corporate networks: The poor, the rich, and the happy few countries. Environment and Planning A, 43(4), 904-927. Wall, R. S., \& Knaap, G. A. V. D. (2011). Sectorial differentiation and network structure within contemporary 
worldwide corporate networks. Economic Geography, 87(3), 267-308.

Wasserman, S., \& Faust, K. (1994). Social network analysis: Methods and applications. Cambridge, England: Cambridge university press.

Whitley, R. (1998). Internationalization and varieties of capitalism: The limited effects of cross-national coordination of economic activities on the nature of business systems. Review of International Political Economy, 5(3), 445-481.

Witt, U. (2003). The evolving economy (number 2477). Books, Edward Elgar Publishing.

Xu, X., Ma, S., \& Zeng, Z. (2019). Complex network analysis of bilateral international investment under de-globalization: Structural properties and evolution. PloS One, 14(4), e0216130.

Yang, C. (2013). From strategic coupling to recoupling and decoupling: Restructuring global production networks and regional evolution in china. European Planning Studies, 21(7), 1046-1063. 


\section{Appendix}

Table A. Normalized Dependent Variable of the Global FDI Network

\begin{tabular}{lll}
\hline \multicolumn{1}{c}{ Concept } & \multicolumn{1}{c}{ Indicators } & \multicolumn{1}{c}{ Sources } \\
\hline $\begin{array}{l}\text { Global FDI connectivity } \\
\text { of countries }\end{array}$ & The degree centrality & FDI data collected from Zephyr M\&As database \\
& & Degree centralities generated using Social network analysis \\
\hline
\end{tabular}

Table B. Explanatory Variables of the Global FDI Network

\begin{tabular}{|c|c|c|}
\hline Variable & Indicators & Sources \\
\hline Market size & Population & World Bank \\
\hline Market accessibility & Trade freedom & The Heritage Foundation \\
\hline Market efficiency & Government spending & The Heritage Foundation \\
\hline \multirow[t]{2}{*}{ Labor } & GDP per worker & World Bank \\
\hline & Unemployment rate & World Bank \\
\hline Technological Advancement & High-tech export per capita & UNCTAD \\
\hline Natural resources & The share of fuels export & UNCTAD \\
\hline National performance & GDP Growth & World Bank \\
\hline Institutional setting & Governance index & World Bank \\
\hline Financial Development & Credit provision & World Bank \\
\hline Geographical regions & $\begin{array}{l}\text { Australasia (dummy variable) } \\
\text { Eurasia (dummy variable) } \\
\text { Latin America (dummy variable) } \\
\text { Middle East \&North Africa (dummy variable) } \\
\text { North America \& Europe (dummy variable) } \\
\text { Pacific Asia (dummy variable) } \\
\text { South Asia (dummy variable) } \\
\text { Sub-Saharan Africa (dummy variable) }\end{array}$ & \\
\hline Urbanization & urbanization rate & UNCTAD \\
\hline $\begin{array}{l}\text { The level of world cities located } \\
\text { in the countries }\end{array}$ & $\begin{array}{l}\text { Countries with first-tier world city dummy; } \\
\text { Countries with second-tier world city dummy; } \\
\text { Other countries dummy }\end{array}$ & $\begin{array}{l}\text { Globalization and World Cities } \\
\text { (GaWC) Research Network }\end{array}$ \\
\hline Path Dependence & Previous FDI stocks & UNCTAD \\
\hline
\end{tabular}


Figure A. Topology of the global FDI network (2000, 2008, 2016)

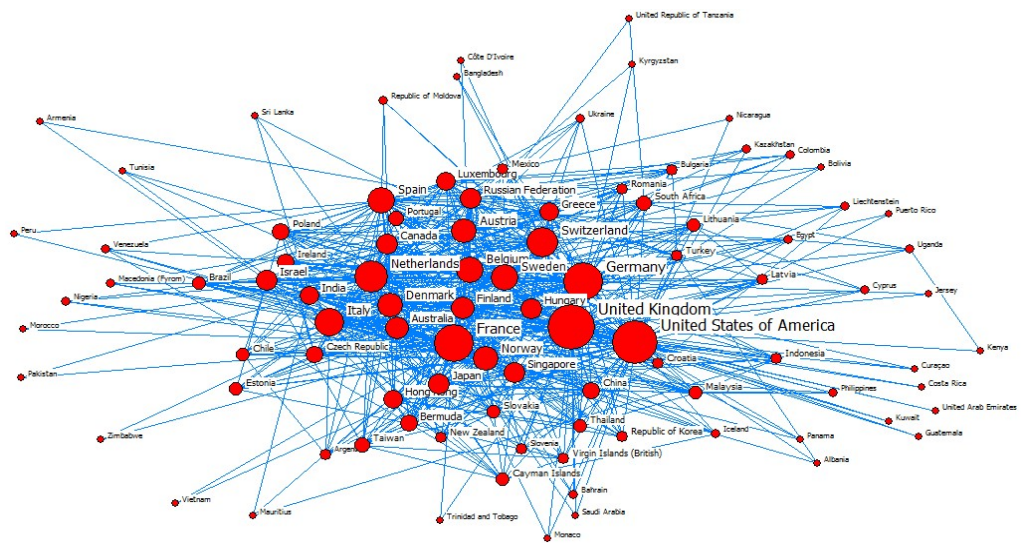

Year 2000

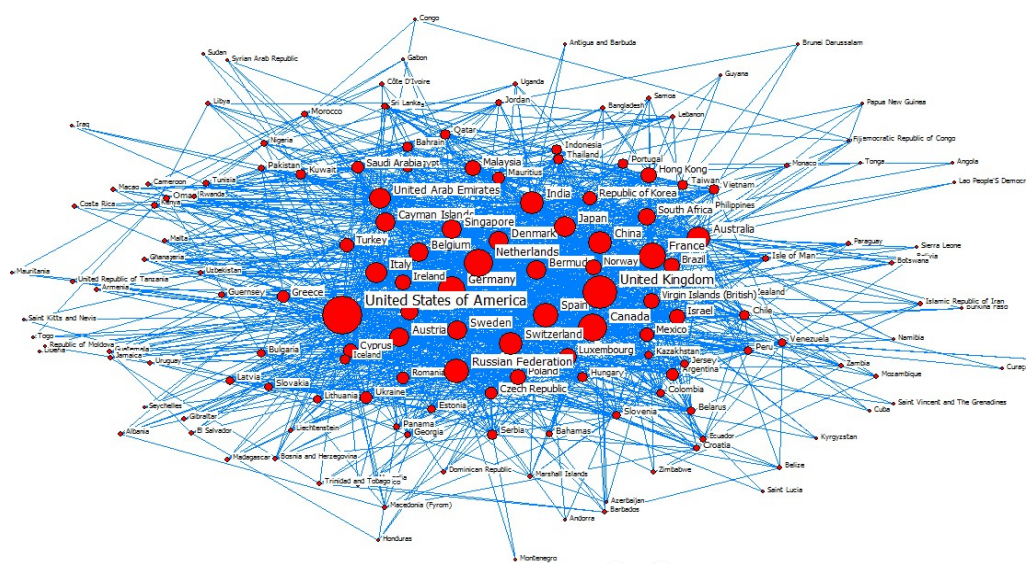

Year 2008

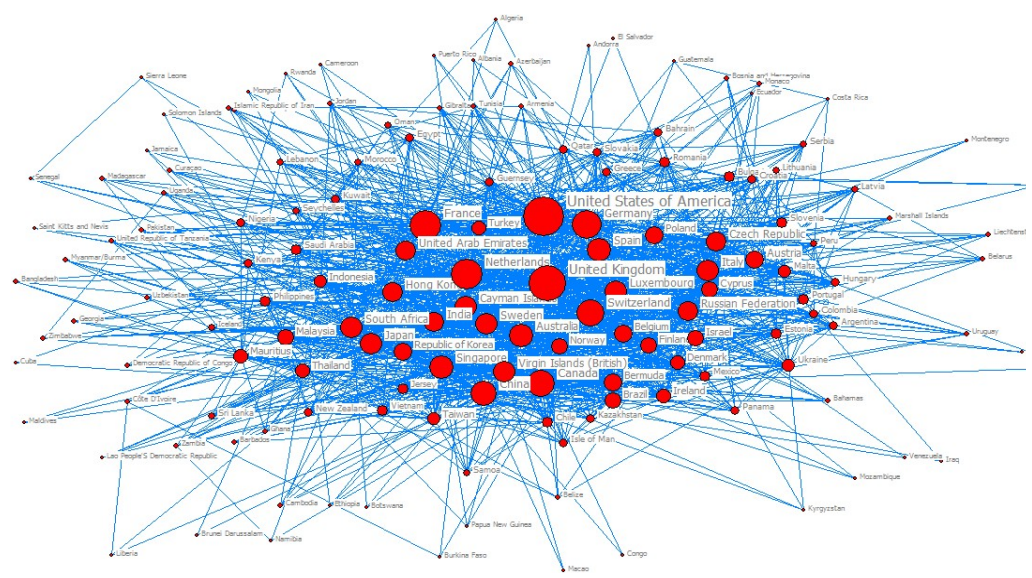

Year 2016

(Source) Zephyr database (Maps generated by the authors, 2020)

Generated using UCINET; (Dots are countries; Lines are investment ties); Node (country) sizes are proportional to their respective degree centrality 